\title{
팔레스타인 지원 국제회의 결과
}

최근 레바논 사태와 더불어 악화된 팔레스타인 의 인도적 위기에 대한 지원방안을 논의하기 위해 35 개국 및 국제기구(약 20개) 대표가 참가한 가운 데 표제회의가 스웨덴 · 노르웨이 · 스페인 정부 공 동주최로 9.1(금) 스톡홀름에서 개최된 바, 동회의 결과를 아래 보고함.

\section{1. 회의 주요결과}

- 금번 회의에 참석한 팔레스타인(Abbas 수반 경제보좌관) 및 UN 대표(Egeland 인도지원 담당 사무차장 등) 등은 팔레스타인의 만성 적인 위기상황이 최근 보다 악화되었음을 설명하고 국제사회의 보다 적극적인 관심과 지원을 요청함.

- 팔레스타인은 전 인구의 $70 \%$ 가 빈곤상태 이며 특히 전기 · 식수 · 식량 · 의약품 등 의 긴급지원이 필요하나 $\mathrm{UN}$ 합동어필
(CAP)의 $31 \%$ 만 지원된 상태임.

- 금번 회의에 참가한 많은 국가들이 팔레스 타인에 대한 인도적 지원확대 필요성에 공 감한 바, 동 회의를 통해 총 2 억불 이상의 신 규 지원서약(pledging)이 발표되었으며 이 중 $\mathrm{CAP}$ 에 대한 추가 지원액이 55 천만불에 달함.

- $\mathrm{EU}$ (5천만유로), 독일(4.2천만유로), 노르 웨이(8백만불), 미국(5백만불), 스페인(3백 만유로) 등 서약

- 사우디아라비아는 금번 회의와는 별도로 2 억 5 천만불을 기서약 발표

- 특히 $\mathrm{EU}$ 는 7.26 개시된 대팔레스타인 임시 국 제 지 원 계 획 (TIM; Temporary International Mechanism)의 활동계획을 설명하고 총 9천만유로를 TIM을 통해 식 
수·보건의료 · 실업문제 등에 지원할 계획 이라고 밝힘.

- 대부분의 참가국들이 팔레스타인 위기에 대 한 유일하고 항구적인 해결책은 정치적 해 결뿐이며 단기 인도적 지원 이후의 팔레스 타인 중장기 발전전략도 고려해야 한다는데 인식을 같이했음.

- 특히 당면한 현안인 공무원 임금체불·정 치인억류·지원물자 접근문제 등이 조속 히 해결될 수 있기를 기대함.

\section{2. 우리측 수석대표 발언 요지}

- 유 차관은 최근 가자 지구의 인도적 위기 상 황에 대한 우려를 표하고 국제사회의 공동 노력으로 현 상황이 조속히 개선될 수 있기 를 희망하는 한편 우리 정부도 이에 적극 동 참하겠다는 의사를 표명함.

- 아울러 그간 우리 정부는 '팔레스타인 교육 시스템 개선사업 등 UNDP와의 공동사업 등을 통해 팔레스타인에 총 12 백만불을 지 원하였음을 설명하고 특히 2005년에는 2006-2008간 총 6백만불을 지원하기로 서 약하였다고 밝힘.

- 현재 제한적인 범위에서 동 지원프로그램 을 이행중인 바, 팔레스타인의 상황변화에
맞추어 조속히 지원약속을 완료할 계획이 라고 설명함.

\section{3. 관찰 및 평가}

- 금번 회의에 참가한 대부분의 국가 및 국제 기구들은 대팔레스타인 지원을 위한 가자 지구에 대한 접근문제(denied access)가 팔 레스타인의 인도적 위기를 악화시키고 있다 는데 공감하였으나 이를 위한 구체적인 해 결책 제시에까지는 이르지 못함.

- 동 접근문제로 인해 대부분의 국가들이 대 팔레스타인 지원에 있어 $\mathrm{CAP} \cdot \mathrm{TIM}$ 등 다 자지원 매커니즘을 적극 활용하고 있는것으 로 나타난 바, 향후 우리 정부도 동 다자채널 을 적의 활용할 필요가 있는것으로 판단됨.

- 아울러 금번 회의에는 우리측 고위인사가 참석하여 우리 정부의 대팔레스타인 지원 현황과 지속적인 지원의지를 표명한 바, 이 를 통해 중동지역 국가들과의 연대를 과시 하고 대중동 외교기반 강화에 기여한 것으 로 평가됨.

[자료: 주스웨덴대사관] 